\title{
Collapsing Fish Stocks, Gendered Economies, and Anxieties of Entrapment in Coastal Sierra Leone
}

Jennifer Diggins

\section{ABSTRACT}

This article explores the economic negotiations between Sierra Leonean fishermen and the women who compete to buy their fish; tracing how relationships of gendered intimacy and interdependence are being reconfigured in a context of deepening economic precarity. Fish stocks in Sierra Leone are in crisis. Fisherfolk look back with nostalgia to a past in which bountiful harvests had made it possible for transactions of fish to be simple and impersonal. Today, by contrast, it is almost impossible for women to access fish without working to develop strong personal relationships with fishermen: deploying gifts of food, loans of money, and even secret 'medicines' to secure the loyalty of potential customers. I analyze how men and women reflect on their growing impoverishment through discourses that emphasize their moral ambivalence at being drawn back into webs of interpersonal dependency and argue that these anxieties need to be understood in the context of Sierra Leone's history of domestic slavery. 


\section{INTRODUCTION}

Loads of men I've known, they left Tissana to go to Plantain Island

- just for a few days, just to make a bit of money - but you never see them back in Tissana again! ... That's why I never sleep on Plantain. The women there will say, 'Why don't you just stay here for one night? In the morning, I'll find you some bait...' No! If I ever land my boat there, I just sell my fish and come straight home! The women who are there, they know how to catch a man... (Kumba, Boat Owner)

Boat captains in southern Sierra Leone often exchange cautionary tales, like this, in which the women in neighbouring wharf towns are represented as powerful seductresses and dangerous economic predators. Having initiated exchange relationships with visiting fishermen through gifts of food, loans of money, and sex, these sirens are described holding men indefinitely; entrapped against their will in binding economic relationships. Although such tales are usually recounted playfully, I argue in this article that they express a real set of anxieties within coastal communities, as people struggle to adapt to the moral landscape of a newly precarious economy. These narratives of entrapment express a broader sense of unease, shared by women as 
well as men, that business transactions are becoming ever more woven within personal entanglements of intimacy, obligation and power.

Based on eighteen months' ethnographic research, this article traces how relationships of gendered intimacy and interdependence are being reconfigured in a context of a deepening ecological crisis. In Tissana, the frontier town in Sierra Leone on which this article is based, fish form the basis of almost every person's livelihood. Almost all working-aged men are sea-going fishermen, whilst most women earn at least part of their living as fish-processors (banda women), buying fish on the wharf and drying them to sell on at marginal profit to the traders who visit Tissana from across Sierra Leonei. For many people, fish are also a source of profound, and deepening, anxiety. Illegal poaching by international trawlers (EJF 2012) and unsustainable practices by local fishing fleets have decimated fish populations and left coastal communities struggling to survive on ever smaller, less predictable, catches.

Although the current crisis has affected everyone in the fishing economy, it has proved especially damaging for female fish processors (banda women) who find it increasingly difficult to secure fish on the wharf. In response to this deepening insecurity, banda women have had to become increasingly strategic in working to build and sustain intimate reciprocal relationships with fishermen, who will then be obliged to sell 
them fish. This article traces these dynamics and makes two related arguments:

Firstly, the article explores the ambivalent power of gift relations to reconfigure social landscapes. When people reminisce about life before the ecological crisis they often idealized a brief period in their past when bountiful harvests of fish had made it possible for fish to change hands according to simple, impersonal logic of supply and demand. Fish had been bountiful enough that anyone with cash could buy them. Today, by contrast, almost every sale of fish is interwoven within complex personal negotiations. This experience reverses Mauss's (2002[1924]) description of a socio-economic trajectory that moves from 'gift-giving' economies, to de-personalized ones in which transactions are held at a greater distance from social relationships. I analyze how fisherfolk reflect on their growing impoverishment through discourses that emphasize their moral ambivalence at being drawn back into webs of interpersonal dependency and argue that these anxieties need to be understood in the context of Sierra Leone's history of domestic slavery.

In conversations about their life experiences and ambitions, fishermen often expressed a preoccupation with the importance - but also the fragility - of personal 'freedom' (Diggins 2015). 'Freedom' is a notoriously slippery concept: one whose meaning, as Isaiah Berlin noted, 'is so porous that there is little interpretation that it seems able 
to resist' (1969: 121). Still, if they are to hold any real emotional resonance, ideologies of freedom must be constituted against a particular, historically grounded, knowledge of oppression. Within Europe and American political philosophy, debates about liberty tend to reflect anxieties about the potential for state oppression (Rose, 1999) but, in Sierra Leone, people's aspirations to freedom take as their starting point a far more intimate historical model of oppression. Up until the early twentieth century, domestic slavery had been one of the most important social institutions in the region (Shaw 2002). This form of servitude often baffled European observers more familiar with the radical, racial violence of New World slave economies. Although they knew it was common for people to be captured, pawned, or tricked into indentured labour, Europeans often had difficulty distinguishing these 'slaves' from the landholders and patrons who controlled their labour (Kopytoff and Miers 1977: 5).

Anthropologists working in Sierra Leone have argued that, even following the official abolishment of slavery in 1928, existing patterns of domination did not disappear so much as become reframed in the language of patronage (Ferme 2001: 171-2; Shaw 2002; Richards 2005). Powerful people have often been described measuring their wealth in terms of the number of clients they are able to 'protect', provide for - and control - often through relationships of debt (Leach 1994). The creation of unequal relationships through bonds of 
indebtedness resonates with Mauss's (2002[1925]) description of the obligations associated with gift-giving. Gifts hold the power to reconfigure social relationships; either creating ongoing ties of reciprocity, or - in cases when gifts remain unreciprocated establishing enduring dynamics of social subordination (cf. Gregory 2015[1982]). In extreme cases, as Mauss had recognized, gift-debt can cause a person to lose social respect and even, potentially, their 'status of a free man' (2002[1925]:54).

Recent ethnography in Sierra Leone has revealed how often patronage relations are characterized by a level of domination and control that recalls social memories of domestic slavery (Peters 2010). In Tissana, one result of this legacy is that people's experience of receiving and reciprocating gifts is often entangled with anxieties about the potential for entrapment (Diggins 2015, 2017). As this article reveals, these anxieties have found renewed relevance in the current economic crisis, as fishermen and banda women their own material insecurity, through relationships of intimacy, interdependence, and the fears of attendant entrapment as clients in the fishing economy.

Secondly, in contrast to existing studies of transactional sex in fishing economies (Westaway, Seeley, and Allison 2007), I move beyond portraying women primarily as victims and explore the implications of this gendered economy from perspective of both women and men. Whilst 
describing the consequences of the ecological crisis on women's lives, my ethnography also reveals men's fears around the obligations linked to the intimate relationships they had forged with banda women in order to sell their fish. This dual perspective challenges Western folk notions about the 'naturalness' of male desire, and the inevitability of their dominance in heterosexual relationships (cf. Wardlow 2004). For, the balance of gendered power in Tissana is complex and variable and, despite the extreme pressure they are under, some women succeed in establishing themselves as formidable local patrons.

As much as it runs contrary to Western folk ideology, anthropologists have long recognized the entanglement of intimacy with economics. From the 1970s, feminist ethnographers in Africa began documenting the agency of women in their everyday interactions with men, often emphasizing how they used sex to negotiate access to material resources (Bledsoe 1980, Leach 1994). This emphasis on the instrumental aspect of intimacy intensified from the 1990s, as anthropologists traced how material insecurity and gender inequality were driving many women into transactional relations that left them vulnerable to HIV. Much of this literature is nuanced and important, but as Thomas and Cole (2009:9) have highlighted, en masse it has served to promote an overly constricted view of love in Africa: one that downplays the complexity of romantic passions, emotional attachments and power negotiations (cf Hunter 2010). In fishing communities in 
Southern and Eastern Africa, for example, researchers have described economies of 'fish-for-sex' in which female fish traders and fish processors tend to appear as victims: forced to 'prostitute themselves' to exploitative fishermen, so as to secure access to a shrinking supply of fish (Béné 2007: 884; Westaway, Seeley, and Allison 2007). As this article reveals, the stark term, 'fish for sex' cannot do justice to the liaisons that develop between Tissana's fishermen and the women who buy their fish. While these relationships may sometimes involve sex, they are characterized by more complex entanglements of affect, indebtedness, and moral notions of patronage and loyalty; as well as deliberate strategies to manipulate 'the purchase of intimacy' (Zelizer 2005) through elicit substances that nurture feelings of desire.

\section{SIERRA LEONE'S FISHING ECONOMY}

Tissana, the site of my fieldwork (from 2010 to 2011), is a busy wharf town with a population of about 5,000 people. Fishing towns (alehns) began expanding in this region from the late 1960s, when visiting Ghanaian fishermen introduced new, efficient technologies for catching bonga; the herring-like fish that move in large shoals through Sierra Leone's Yawri Bay. Within a few decades, Tissana had grown from a tiny subsistence hamlet into a thriving, cosmopolitan centre of commercial fishing, fish processing, and trade. Dried fish is a key source of affordable 
protein in West Africa, particularly in urban areas, and Tissana's fish are sold marketplaces throughout Sierra Leone and beyond.

After fifty years of in-migration, by migrants from rural areas of Sierra Leone, the original Sherbro population is now far outnumbered by Temne, Mende and Fula-speakers. For many of these migrants, part of the appeal of this maritime frontier was that the openness and fluidity of the commercial fishing economy appeared to offer an alternative to the stifling patronage relationships that characterize 'traditional' agrarian villages (Diggins 2015). Even now, with bonga populations in decline and the fishing economy under increasing pressure, coastal towns continue to attract new migrants in search of a new kind of life on the sea.

'Her man' (in man) and 'his woman' (in uman) are the terms most often used to describe the partners in any socially recognized heterosexual relationship. In Tissana's fluid world, these are malleable categories and can apply regardless of whether the two people are formally married, have had children together, or cohabit; indeed, they apply regardless of whether they even live in the same town. Spanning this diverse range of relationships, the one thing that is relatively certain is that, wherever these terms are used, there will be an important public economic dimension to the partnership. 
Whilst is quite common for a woman to co-own a fishing boat with 'her man', boats are regarded as inherently male spaces, and, in everyday speech, most couples slide towards referring to the man as boss-man [owner/manager] of 'his' boat. However, this rhetorical slide refers only to one specific form of power, explicitly located within the delimited male space of the sea. As one boss-man was keen to stress, there are important respects in which women are regarded as more powerful than their fishermen counterparts.

We [fishermen] just bring in the finances, but to control those finances is a problem for us... If you want to lead a better life in a fishing community as a man, you must have a strong woman. You must have a strong woman in the home who can manage the finances. (Ben, boat owner)

As a result, most of the largest smokehouses (bandas) in town belong to the wives of the men who own the biggest boats. Even so, it would be rare for their conjugal finances to merge completely. Here, as in rural parts of Sierra Leone, husbands and wives typically maintain separate income streams and expenditures (Leach 1994: 189). What this means is that many women buy fish from their husbands then sell it on to their trader clients (kustoments) at a small profit. 
While it is generally the case in Sierra Leone that women are 'less educated, make less money, and are legally and politically subordinate to men' (Coulter 2009: 71), there have always been examples of resourceful, ingenious women becoming successful entrepreneurs and wealthy patrons (Ferme 2001, Leach 1994). Women in Tissana are no exception. As my ethnography reveals, there are huge differences in the range of resources that different banda women are able to wield in their relationships with men.

\section{THE SUBSTANCE OF FISH AND RECOLLECTIONS OF A 'FREE' MARKET}

To understand gendered transactions in this coastal economy it helps to begin by considering the particular material substance of raw fish. In Sierra Leone's hot, humid climate, raw fish rot fast. Fishermen have no choice but to sell their catch the moment they return to land. On the other hand, every banda woman has a limit on the amount of fish she is able to dry. This depends on her capital, the size of her banda (smokehouse) and her supply of dry wood. These material constraints combine with the inherent unpredictability of fishing: on a day when twenty-five boats go to sea, it is impossible to forecast whether one or seven or none at all will return to land with a substantial catch. The result 
is that extreme fluctuations in fish supply translate into equally extreme fluctuations in the price women are prepared to pay for those fish.

Whenever I asked people to recall their town's economic boom in the 1970 s and 80 s they would almost always emphasize, as Pa Bimbola does here, that, 'Sometimes, there were so many fish they had to just throw them away. If you went to the wharf, they'd give you fish - sometimes even a huge panful!' Below, one of Tissana's experienced fish processors paints a vivid image of the fishing economy when the Yawri Bay had seemed to contain inexhaustible riches:

At that time, if you stood on the land... you'd see them; it looked like the water was boiling... with the fish jump, jumping... they'd take their net and cast it - catch so many fish! (Sina, banda woman)

What is striking, as Sina continues her account, is that for fishermen there had been a limit on the value of these enormous catches - which often exceeded the amount local women were prepared to buy. The closest urban fish market is well over a day's journey away, so any fish that were not dried immediately would rapidly decay from a valued source of wealth to a stinking liability: 
If they'd caught a lot of fish then, at dawn, the chief would walk around all the bandas and, if he smelled rotten fish, he'd summon that person [to court]. Because rotten fish attracts flies, and flies spread diseases... So, eventually, the boat owners - they'd just dig a hole in the sand and cover them up, so as not to let them smell. We couldn't finish them all. There wasn't enough wood to dry them (Sina, banda woman)

Looking back to this time, men and women remember patterns of bargaining on the wharf as having been driven by the simple mechanics of supply and demand. Provided she had enough money, anyone who came to the wharf could buy as much fish as she was capable of drying. If several boats landed a good catch on the same day, the cost of the fish would fall until, eventually, their value bottomed out entirely:

If you had money, you'd dry; you'd fill your banda full - pim! At first, they'd sell for 5,000 leones [per large pan]. Then the price would drop; 4,000, 3,000... But, if they saw that no one else was coming, ... They'd just leave the fish on the wharf and call, 'You who have bandas, who have wood, come and gather! Don't let the fish rot!' And they'd just give you!

By the time I arrived in Tissana in 2010, dynamics of the wharf had shifted dramatically. Although the volume of catch on the wharf 
fluctuated sharply on a day-to-day basis, the longer-term narrative I was repeatedly presented with was one of gradual but dramatic decline. In fact, the most urgent problem nowadays concerning banda women is not what price they are able to bargain for the fish, but whether they are able to buy any fish at all.

Just as men must use all their skill and strategy to hunt fish on the open water, the same is equally true of women hunting fish along the beach. Many banda women pass a large part of each day meandering up and down Tissana's two-mile wharf, attempting to match their movements to coincide with the (only very loosely predictable) arrival times of the different boats. Where they accumulate at the landing sites of particularly large boats, banda women form the focus of a vital, but transient, gendered social space within Tissana. As they sit waiting, sometimes for hours - watching the sea, braiding one another's hair these would-be buyers are joined by other women; sometimes with pans full of fruit to barter, sometimes with cakes or cooked food to sell.

When I asked one of these waiting banda women whether she intended to buy fish from the boat when it arrived, she had laughed at the silliness of my question: 'If they sell-gi me, I'll buy!'. This compound verb, sellgi - meaning, literally, to 'sell-give' - was not used in any other context in Tissana. It captures an important quality of the transactions that take place on the wharf each day. Regardless of the fact that the banda 
woman had come to the wharf with cash, fully expecting to pay for any fish she managed to procure, her words have embedded within them the understanding that, if any transaction transpired, the fisherman would see himself as doing her a personal favour.

When the boat finally lands, a complex unspoken web of obligations and loyalties will determine which banda women are able to buy fish, and which return home empty handed. It is common for a crowd of fifty or more women to gather at the landing sight of Tissana's largest boats. Yet, on a typical day, only a small fraction of these women will bother to stir from their seats when the fish begin to be carried ashore. Others may linger on, watching hopefully as the fish are turned out onto the sand, but most, seeing the disappointing size of the catch, begin to drift off in search of another boat.

For all their seemingly opportunistic movements up and down the wharf, banda women know very well which men are likely to sell them fish, and under what circumstances. Put simply, the only way for a banda woman to secure a reliable supply of fish is to establish a 'kustoment' (trading partner) relationship with a fisherman, who is then obligated to give her first refusal on his catch. Although they will buy opportunistically wherever they can, many banda women have only a single regular kustoment. Usually this will be her husband, as their business relationship is closely interwoven with their personal one. 
Unfortunately, if a banda woman's partner is himself a poor crew member, his custom alone does not go very far toward securing a steady supply of fish. Crewmen are typically 'given' two days each week to divide the boat's catch amongst themselves, each channeling his share directly to his own kustoment. For the rest of the working week, the catch belongs to the boat owner and it is his decision who to sell-gi. Yet, even on these days, one can expect to see all the wives of the crew waiting at the wharf for their husbands' boat. Their personal connection to the boss-man gives them reason enough to hope they may be offered the opportunity to buy some of the surplus - after his own wife's banda is full. This is by no means guaranteed, however, and they will be competing with various other women - relatives, friends, perhaps girlfriends of the boat owner - each of whom has her own special social claim to buy a share of the catch.

This straining of rather too sparse resources across rather too stretched social networks is a common feature of life in Tissana; and one that stands in sharp contrast to a not so distant past in which fish were in such plentiful supply that, as we hear these two elders reminiscing of life in the 1970s,

'Everyone would sell to everybody... There was no discrimination' (Pa Kwashie). 
'Yes... before, there were no regular kustoments at that time. Whoever had money, could buy. This fish was plentiful. We'd get a good catch! I think the people who were here before were more lively than now. There was more happiness. The money was flowing.' (Pa Yannie)

What I want to emphasize here is that the elders are not just expressing nostalgia for lost material bounty of this era, but also for what they remember as a simpler, more impersonal market economy. This forms an interesting counterpoint to the substantial body of classic ethnographic literature, describing the anxiety people experience when previously complex 'gift economies' are eroded by the depersonalizing forces of money (Bohannan 1959; Burkhalter and Murphy 1989). In Tissana, whereas it had once been possible to buy and sell fish with little thought for anything other than the simple calculation of profit, the wharf side economy is nowadays 'permeated with [the]... atmosphere of the gift' (Mauss 2002 [1925]:83), as exchanges of fish carry an increasing weight of social, political, and emotional significance.

In their conversations with me, prosperous boat owners were explicit that, whenever they choose to sell fish a poor banda woman, they perceive these commercial transactions as acts of generosity. For example, in the quote below, Sento, a wealthy boat owner, explains that she expects her sales of fish to generate relationships of moral 
indebtedness, in which banda women are obliged to perform 'gratefulness':

I have my own boat but on some days I don't [keep the fish to] dry, I sell-gi to my colleagues. [For example, if] you and I knew one another, I'd help you... I'd sell-gi to you. If I sell-gi to you... you'll be grateful to me.

There are important social consequences to reconceptualizing an economic transaction, as Sento does here, as a 'gift' that cannot be fully reciprocated with cash. As Mauss had recognized, the 'unreciprocated gift... makes the person who has accepted it inferior' ([1925] 2002: 83). As discussed in the introduction, unreciprocated gifts, in the Sierra Leonean context, are typically understood through the moral lens of patronage and dependency, with all the ambivalent inequalities this implies. The concept of being 'for' or 'behind' a patron who provides material protection permeates social relations (Leach 1994: 187). By reframing their sales of fish as 'gifts', and structuring their customers as dependents, boatowners are therefore making a claim to considerable social prestige and political power.

For their part, small-scale banda women try to resist the implication that they ought to feel indebted to the boat owners who sell them fish. Instead, they emphasize how poorly they are rewarded for dirty, 
grueling physical labour that requires them to spend a large part of each day in swelteringly hot, dark, densely smoke-filled bandas. After carrying heavy loads of fish and firewood across town, they gut and clean the fish, and arrange them over a fire to smoke. Banda women must then stay up through most of the night watching ensuring their fish do not burn. At daybreak, they turn the fish over, fetch more firewood, and begin the process again. Because the rhythm of their days is determined by the time it takes for fish to dry, this punishing routine continues unabated, regardless of whether they manage to procure a decent load of fish on the wharf, or only a tiny quantity of low-value fish.

The steady slide in the balance of supply and demand on the wharf has eroded women's bargaining power, such that women often found themselves struggling to work within a stiflingly narrow profit margin. What is being 'given' is not wealth itself but only a narrow crevice of opportunity through which, perhaps, to make some. I suggest, therefore, that whilst the ecological decline is affecting everyone in the fishing economy, it has been particularly damaging for banda women, who now find it increasingly hard to buy any fish at all. As I explore in the following section, women have responded to the economic crisis by learning to be increasingly strategic in working to build and sustain social relationships with fishermen that will enable them to access a supply of fish. The level of skill this involves should not be underestimated. 


\section{MAKING KUSTOMENT RELATIONSHIPS}

Throughout my research in coastal Sierra Leone, I watched as my good friend, Jacob - a respected elder - struggled and repeatedly failed to establish himself as a small-scale fish processor and trader. More days than not, I saw him return home dejected and empty-handed, complaining, 'This scramble for fish is just too much'. Eventually, I asked one of Tissana's most successful businesswomen, Hawa, why it was that Jacob experienced such difficulty, even on days when he had plenty of money to spend. She answered that:

Even if you don't have a kustoment, you can still buy fish, but you have to talk to the fishermen fine; greet them fine; turn-turn [cajole; coax] them fine! If you just stand there on the wharf with your money, you won't get anything!

Hawa notes, then, that a bit of strategic flirtation can go a long way to persuading boat owners to sell her their surplus fish; and it may be largely for this reason that Jacob was experiencing such difficulties in what is, after all, a highly gendered role. Her response also hints at the moral tensions which so often riddle these gendered transactions of the wharf. Whilst she is perfectly open that her feminine charm is part of what makes her good at her job, the Krio term she uses here - turn- 
turn - is hardly an unambiguously positive one. In fact, it is often used by people to describe situations where they consider themselves to have been manipulated, or conned.

But, in the current ecological context, it takes a lot more than charm to become a successful banda woman. To illustrate this, I introduce another of Tissana's most respected banda women - Ami. Ami was constantly on the move; all day, back and forth, meeting one boat after another and shuttling fish, often in small, piecemeal lots, back to her banda to be dried. Unable to rely on her husband (who was a heavy drinker and had long since stopped going to sea), she had, over the years, managed to accumulate over a dozen small-scale kustoments. They were mostly young crewmembers who, having arrived in Tissana as strangers, had found a valuable ally in Ami.

When I asked Mohammed, a poor crewman, why it was that he chose to work with Ami rather than any of the other banda women in town, he immediately emphasized that he valued the mentoring aspect of their relationship:

Sometimes she'll call me; advise me. When I first came here, and she didn't know me, she saw that my eyes were red [like a person who has been smoking marijuana] so she took me aside and said, 'Please, you've come from far away to come here; don't get 
involved in that nonsense!'... We've been kustoments for years now.

Ami's importance to her kustoments went far beyond simple moral support. One evening in the rainy reason, I stopped by her banda and found her serving up rice from a pot that was - even by Sierra Leonean standards - cavernous. Just as I was wondering what she could possibly be doing with such a vast quantity of food, Mohammed arrived with a pan to collect a serving for himself and his wife. Mohammed lived at least half an hour's walk away, at the other end of town but, not having gone to sea for several weeks, he was more than prepared to make the journey to collect his dinner.

Even a relatively successful fisherman can never be certain on a day-today basis whether he will catch enough to meet his basic household needs. For those who opt to work with a banda woman other than his own wife, receiving this steady food supply from outside his own household can go a long way toward evening out these fluctuating dayto-day insecurities.

What gives these gifts an added salience is that, in other contexts, people often stress the danger inherent in accepting gifts of food; that, by doing so, they expose themselves to the mercy of their benefactor. 'Bad medicines' (ifohn wei) are assumed to circulate widely through 
Tissana's covert economy, and in a bewildering array of forms. At one extreme are rare, dangerously potent substances reportedly made from the body parts ${ }^{\square 2}$ of people murdered for this purpose. But, at the other end of the spectrum, medicines used to influence people or secure their loyalty are considered a fairly mundane element of day-to-day economic life. Viewed within such an atmosphere of widespread mistrust, the kustoments' small daily taken-for-granted acts of giving and receiving take on an added salience and play an important role in transforming economic interactions into social ones. By publicly receiving and eating her food each day, the fisherman implicitly resigns himself to the fact that, if she wanted to, his kustoment could and would use this power to 'influence him' with ifohn wei - but that he trusts her not to exploit this power.

Returning to Mohammed, these gifts of food were, for him - as for many of Ami's kustoments - far more than a symbolic gesture of goodwill or trust. Not only a poor crewmember, but also a 'stranger' in Tissana, Mohammed was in a doubly vulnerable position. Throughout the long, rainy season of 2011, Mohammed's boat was plagued with technical problems. Very few crewmen can afford the luxury of saving money; so, particularly for strangers like Mohammed, with no local network of kin to whom they could turn in time of need, periods of enforced economic inactivity put them under enormous strain. That he was able to cope at 
all came down, in large part, to his relationship with Ami, as he explained:

If we don't go to sea then we don't get anything, even if we are working on mending the fishing nets. We have stable kustoments. So, if you're my kustoment; any time that I'm broke, I'd come to you and say, 'Jennifer, I don't have any money'. You'd lend me something. I don't pay it back bulk-oh! Small-small, small-small [very gradually] ... Even last year, when my woman was pregnant - at that time, I didn't have any money, so Ami lent me 100,000 leones. I paid it back small-small, until I've paid her back now. She never once shouted at me. Me: I like to be secret. I don't want to expose my business. So that was the thing that made me like her more.

Given that many banda women find it increasingly difficult to secure access to a regular supply of fish, it is easy to see the benefit to Ami of keeping her suppliers in debt. However effectively fish sales may be channeled by love, friendship or habit, it is only when a fisherman owes a banda woman money that she has the right to summon him to court if he sells to another woman. This puts rather a different light on Mohammed's gratitude that, as he was so keen to stress, Ami has never pressured him to repay her anything other than 'small-small, smallsmall'. As Charles Piot noted in Ivory Coast, 'giving is always tied up with 
control, power, and the appropriation of an other. The other is in your debt and must "respect" you' (1999: 70). Although she never charges her kustoments interest on these loans, Ami nonetheless profits directly from their indebtedness to her; for it buys her the loyalty she needs to secure a reliable supply of fish for her banda.

For someone as vulnerable as Mohammed to be so routinely indebted to his far more prosperous and better-connected trading partner, one could easily imagine this might foster a potentially exploitative power dynamic. Yet, however unequal he and Ami may have been in terms of their social and material capital, it is clear from Mohammed's own account that he considers Ami to have liberated him from an altogether less appealing possibility:

If I went to my boss-man and told him [I needed help], he'd help me. But I don't want that. I don't want to be in debt to my boss. I prefer to borrow from my kustoment... [because] even if I decided to switch to different boat, I'd keep my kustoment.

For a poor crewman like Mohammed, it would be hard to overstate the importance of this freedom - to 'decide to switch to a different boat'. Unexpected expenses, such as medical costs, occur now and then in the life of every crewman that they are unable to afford without turning to someone more prosperous for help. Put in a similar situation, many 
would opt to borrow from their boss-man. But, as Mohammed explains here: 'If I borrowed money from [my boss], I'd be frightened to leave him in case he took me to court.' In the Sierra Leonean moral imagination, there is longstanding ambivalence about the potential of patrons to abuse their power (Ferme 2001; Peters 2010), and crewmen are acutely aware of how easily debt can become a route into exploitation and bonded labour (Diggins 2015). In conversation, people often described crewmen who were indebted to their boss-man as being 'like slaves'. As discussed in the introduction and previous section, these contemporary forms of patronage bear a residual similarity to the inequality that characterized slavery in Sierra Leone in the early 1900 s (Ferme 2001: 171-2; Shaw 2002; Richards 2005).

And yet, throughout Sierra Leone, vulnerable people continue to hope, sometimes in vain, for a fair and responsible patron who will protect them and help them to navigate a threadbare economy (Bolten 2008, Menzel 2016). In Tissana, as elsewhere, people are struggling to 'creatively resuscitate' (Gale 2006:78) new kinds of social networks that provide the only real safety net in the absence of any state security system (Diggins 2017). For Mohammed, forging a relationship with a strong banda woman is a compromise: one that affords him the basic security of having a patron, without placing him (too explicitly) in the role of an indentured dependent. However, as we will see in the following section, this kind of relationship is an uneasy compromise. 


\section{ALEHN RELATIONSHIPS}

The one thing all successful banda women have in common is that they have learned to be highly strategic in creating and managing their relationships with fishermen in order to secure access to that seemingly evermore scarce and precious resource: fish. The myriad small negotiations that go into 'making' any relationship as durable and intimate as that between a fisherman and his long-term kustoment are simply too many and too subtle to be easily summarized. Emerging as they do from far longer-term processes of emotional and economic entanglement between two individuals, these relationships extend well beyond the wharf, into kitchens, bedrooms and imaginations around Tissana.

However, there is one context in which kustoment relationships are forged with a special urgency and a stripped-down simplicity on the wharf. When, as is often the case, fishermen take their boats and go 'on alehn' to base themselves briefly in another fishing town along the coast, boat captains must rapidly form new trading relationships in order to sell their fish.

As we have seen, fishermen often place a strong ideological emphasis on the aspiration to personal freedom. Perhaps the most vivid expression 
of this aspiration is the way in which they explicitly valorize their fluid migratory patterns. It was common for fishermen to make a rhetorical analogy between their own fluid, unpredictable migrations and the equally unsettled movements of their fishy quarry, unseen beneath the water's surface. 'Just as the fish migrate, so, too, the fishermen migrate... The fish go, the fishermen go. The fish stop, fishermen themselves stop. Anywhere they go, the fishermen will go there, too' (Ben, boat owner, Plantain Island).

Today, a combination of outboard engines and mobile phone technology has made it possible for boat captains to move intuitively, relying on hearsay to judge, day by day, whether it might be worth trying their luck in a different fishing town:

There are so many alehns. My own boat has just gone to Tombo - we hear the fish are dying there just now. They will go and lodge for one week, they will look at how the fishing conditions are there. If they see the catch is poor, then they'll come back here... Or perhaps I'll call them, and say, 'Come! Come over here! Fish are here!' (Timbo, boat owner, Tissana)

This one word, alehn, captures much of what is distinct about not only the lifestyle, but also the position from which the Yawri Bay's fishermen view their world. In one sense, to alehn is a verb: to move, to migrate fluidly through the water, often not knowing with any certainty where 
one might settle, or for how long. In its other usage, an alehn is also a place. It is the generic name that migratory fishermen give to 'other' coastal towns viewed from the sea: a location etymologically defined by movement and impermanence.

In this second sense, Plantain Island stood in the imaginations of my interlocutors in Tissana as the strongest example of an alehn they knew: a dynamic, unstable town, through which every cliché of fishing life could be illustrated. Having been established as a makeshift camp in the late1950s, this 'temporary' outpost rapidly burgeoned into the most frenetically busy fishing centre in Sierra Leone. Nowadays, Plantain's beach is incessantly busy with boats being hauled out into the sea or back up onto the sand. As fishermen jostle directly with traders on the beach, everywhere one looks people are pulling fish from nets, packing dried fish, negotiating a deal. As one local resident described:

This is the area, here, where money flows! We have fishermen here from as far as Senegal. And we have traders coming from... all over the country! ... You can't sit down and idle here - just sit down and relax. Oh no! Those who go to sea, go to sea. Those who sell, sell. Those who buy, buy. That's it! That's the way we move here! (Sufyan, boat owner, Plantain)

Sufyan's description of his island home as a node in wider currents of migrant fishermen, cash, and trade goods, portrays the fishing economy 
as a world in which coastal communities are integrated, rather than divided, by the ocean (cf. Hau'ofa 1993). The most experienced boat captains are highly tuned to the shifting dynamics across their watery region: not only where other boats are experiencing fishing success, but also how the prices are fluctuating at different points around the coast:

In every alehn, the price can change. Like here in Tissana, for now, they buy bonga for 700 leones per dozen... But right now, in Plantain, they're buying them for 1,500 leones per dozen. Nownow-now! The difference is too much! So, people decide to leave here and go to Plantain.

There was one thing which all fishermen agreed with equal enthusiasm would never constrain their choice of destination; that is whether or not the crew had any pre-established personal contacts in that particular town. Here, Foday emphasizes the strong sense of camaraderie which young crewmen like himself tend to experience on arrival in an unfamiliar fishing town;

Fishermen, we all move around so much; anywhere we go, we are like one big family. We are all brothers... Any alehn you go to, fishermen will welcome you, find you a place to stay, food to eat, even clothes to wear! Yes! They will even take their own trousers 
and give them to you. They know that, if they came on alehn to you, you would do the same for them.

As rapidly as alehning fishermen are able to form new relationships on unfamiliar wharfs, the gendered flip side of this dynamic is predictable. Many women live with a palpable sense of insecurity, knowing that their partner is perfectly liable to relocate at a moment's notice, moving to a different wharf town and taking up a new life with a different wife and business partner. In their conversations with me, banda women often discussed their anxieties about abandonment in very material terms as the severing of an economic partnership, which left them far more vulnerable in the aftermath. So, the freedom and mobility that fishermen so actively valorize is often experienced as a source of considerable anxiety by the women whose lives and livelihoods are entangled with theirs.

Yet, despite their real - and justified - anxieties of abandonment, it would be rather too simplistic to view banda women as the guileless victims of their menfolk. Rather, the difference between these gendered experiences serves to highlight the tensions inherent in a social world as mutable as Tissana's, in which the momentum toward establishing relationships and the desire to disentangle oneself from them are often held in dynamic opposition. 


\section{PLANTAIN ISLAND SIRENS}

The image which emerges here, then, is one in which men and women inhabit quite different landscapes. There are interesting parallels here between the ways in which gender has come to be mapped onto the coastal topography through everyday practices associated with commercial fishing, and other, much longer-standing patterns of gendered segregation. For as long as we have ethnographic records about Sierra Leone, it has always been the case that people experienced their landscape as powerfully gendered.

Gendered initiation societies play a central role in customary politics and have been capturing the imagination of European visitors for at least the past two hundred years (Winterbottom 1803). Although often described in English as 'secret societies', the label does not refer to a society whose membership is secret. On the contrary, almost all men are joined into the lower echelons of the Poro, whilst practically every woman is a member of the Bundu. In the past, young people would have spent several months or years secluded in their respective society's 'bush': a sacred space carefully segregated beyond the limits of the public landscape of the village. During this period of separation, children were transformed into fully gendered adults, learning important life skills and passing through a series of physical ordeals and bodily transformations.

In Tissana as in most parts of contemporary Sierra Leone, society 
initiation is now a much quicker, simpler process; particularly for young men. However, it remains the case that certain important decisions and pivotal life events can only take place safely in gendered seclusion, in the Poro or Bundu society 'bush'. Ethnographers have suggested that the aesthetic of secrecy, so clearly epitomized by the high fences and esoteric practices of the region's initiation societies, also finds expression across a whole range of more 'banal' contexts (Bellman 1984; Ferme 2001).

Bundu and Poro ideology has historically cast as potentially dangerous, but also as powerfully productive, any boundary space in which men and women come into contact beyond the careful regulation of society laws. Indeed, powerful society elders derive part of their mystique precisely from their ability to flaunt the dangers inherent in these liminal spaces (Bledsoe 1984). Within the contemporary commercial fishing economy, 'men's space' has come to be segregated from 'women's space' in new ways. Heightened patterns of male mobility, combined with the importance of heterosexual trading partnerships, create a coastal topography in which men and women routinely find themselves operating across highly charged gendered boundary zones. When alehning fishing crews land their boats on the shore of an unfamiliar wharf town, they enter straight into potentially complex economic relationships with women about whom they know almost nothing. 
A tiny area of land just two miles off the coast of the Shenge Peninsula, Plantain Island is Tissana's closest alehn. It happens also to be the busiest and most profitable fishing centre in Sierra Leone. In theory, then, a short stay on Plantain ought to be as profitable as it is convenient for Tissana's boat owners. Yet, many of the more experienced boat owners and captains claimed to view the island with considerable trepidation. Sumaila, for example, assumes that his boat would be instantly welcomed in any unfamiliar fishing town. However, unlike his crewmen - who described this hospitality as an expression of the natural camaraderie amongst fisherfolk - Sumaila takes a rather more cautious view. As he explained:

There are so many alehns! You can go anywhere you want. If you hear fish are dying in Bauma, you go to Bauma... Even if I've never once been there before, I can go. The only thing is, on the day that I arrive, I should come with fish... That fish there - it is that which will open all my subabu. Yes! That fish: it will make them lodge me fine, in a fine place. It will let me live there well; make them give me respect.

Subabu is a Krio word describing a person's network of useful relationships. It is striking that, in the absence of any pre-existing subabu, it is the catch - not the men themselves - that Sumaila credits as having the power to forge these new relationships. Rather than viewing friendships as emerging from a natural affinity and the shared 
rules of good hospitality, Sumaila assumes that the 'friendliness' local residents is motivated by the desire to desire to profit from their relationship with the visiting fishermen. Viewed in this light, the feminine attentions of local banda women are regarded with particular cynicism.

From the perspective of banda women, visiting boats full of (locally) unattached men offer a rare and tantalizing opportunity: to gain access to a fresh supply of fish and, potentially, to initiate a new long-term kustoment relationship. But competition is fierce, and women have to act very quickly to capture the fishermen's attention when a new boat arrives. Sumaila's account of what happens when he alehns to Plantain Island is typical of the way in which boat owners and captains describe these encounters, with something between attraction and misgiving:

They want your fish; but they want you, too! Like myself, I have a boat, so... the moment my boat lands, the women all come around! They come around and talk to me like they already know me; they'll bring me fine food... She'll come and lean her head on me; she'll just linger on me now; she'll talk to me closely now... That's how they do it. (Sumaila, boat owner)

I once spent an afternoon with two boat captains, Ibrahim and Kumba, as they swapped ever-inflating tales of their encounters with women on Plantain Island. I had rarely seen the two men so animated, as they described the extents (they claimed) the women were prepared to go to, 
in order to entice boat captains into trading relationships: flirting outrageously and making brazen sexual propositions whilst simultaneously offering wads of cash for the men's catch. In their cartoonish portrayal of these gendered encounters, Ibrahim and Kumba represented boat owners as defenseless against the onslaught of feminine wiles; incapable of making rational decisions about who to sell their fish to. So, while exchanges of 'fish for sex' (Béné 2007: 875) are usually analyzed as evidence of women's desperation and exploitation, my research suggests that in the Yawri Bay people were more likely to make exactly the opposite assumption. Faced with a wharf full of unfamiliar banda women, all vying to secure his custom, it was my male interlocutors who described themselves feeling vulnerable to manipulation.

Dominant narratives about how sex becomes entangled with economic exchange typically present women as objects of desire, rather than as agents with complex motivations and desires of their own. Holly Wardlow observed that, 'Since in Euro-American constructions of gender it is women who are "naturally" the objects of desire, it is, of course, women who withhold sex, sell sex, and variously bargain with the one chip they automatically have regardless of other conditions' (2004: 1027). Whilst there is a transactional element to many gendered relationships around the Yawri Bay, it would not be appropriate to describe women 'selling' sex. Rather, material gifts flow in both directions, in reciprocal 
exchanges that are often initiated by women with the hope of nurturing an ongoing kustoment relationship. Moreover, the sirens on Plantain Island are not assumed to be 'naturally' desirable; rather, they are described as working hard to become irresistible by mobilizing an array of overt and covert material resources.

One thing which is interesting about these tales is that they seem to compress, into a single, highly charged encounter on a foreign wharf, many of the elements that characterize the longer-term negotiation of gendered economic relations at home. An undercurrent of sexual tension is certainly one facet of that encounter - and the one the men most enjoyed recounting - but boat owners also described being offered loans of cash by the women hoping to secure their custom, as well as gifts of food assumed to be laced with ifohn wei [bad medicines]. In the quote below, Kumba - a boat owner - expresses an anxiety of entrapment, explaining that women use these various resources in order to 'catch' alehning fishermen.

If you say... that you don't want a girlfriend, they'll say, 'Let me lend you money for petrol.' They have their little handbags, where they keep their money and their ifohn wei, which they put in your food (Kumba, boat owner).

This is a world in which it is impossible to disaggregate the strategies by which people set out to influence one another's bodies from their broader 
efforts to build the intimate relationships that enable them to navigate the tight economy. As already discussed, people are usually wary about accepting gifts of food. At home in Tissana, the flow of rice between a banda woman and her long-term kustoment can be read as evidence of the implicit trust between them. On these foreign shores the gifts are received with a heightened sense of anxiety.

The stories that men share about the Plantain Island sirens, draw their emotional energy from the ways in which they recall longstanding histories of indentured labour, the risks inherent in boundary spaces, and the fine line between seduction and predation. In Tissana, as across West Africa, people are familiar with stories of Mami Wata - a seductive, fearsome spirit, often described enticing her devotees into a watery prison with false promises of lavish wealth. Seemingly modelled on the mermaid figureheads that adorned European slaving ships, folktales about Mami Wata remain a powerful and motif for reflecting on contemporary experiences of economic violence (Argenti 2010). Plantain Island had once been the site of one of the busiest slave forts on the Upper Guinea Coast, so it is striking this liminal space continues to be imagined as a site in which the lure of economic riches, and the fear of personal entrapment, come together in the figure of a powerful female seductress. As one fisherman recounted: 
You want to come home, but they don't allow it. They talk to you fine, they wrap-wrap themselves around you, kiss you... Or, the ones who have money, they take money and lend it to you! They're bad-oh! So that, when the time comes that you're ready to leave, then they'll ask you about the money. They say, 'Eh! You want to go? What about my money? Why don't you just stay in this water here first? The fish are dying so...' You sit down. (Kumba, boat owner)

The accounts in this section highlight how gendered relations are created through the exchange of cash, food, intimacy and elicit substances. They also reflect the deep-seated concerns about entrapment that men experience on finding themselves drawn into relationships that may turn out to be as binding as they are transactional.

\section{CONCLUSIONS}

Fishing never was a predictable business, but it has become radically less so in recent decades. By drawing on both men and women's experiences of Tissana's deepening ecological crisis, this article has

revealed that, as the fishing economy declines, gift relationships have become more central to economic life. I began by describing the highly caricatured way in which fishermen describe women in neighbouring wharf towns, as powerful sexual-cum-economic predators. As Andrea 
Cornwall observed, gossip that stigmatizes successful women as 'voracious temptresses' (2002: 964), sometimes masks a deeper set of anxieties about economic decline, and its impact on men's expectations for their own lives. In Tissana, narratives of gendered entrapment are just one expression of a broader sense of unease, shared by women as well as men, as they adjust to a new moral landscape in which depleted fish stocks have led economic transactions to become increasingly entangled with personal entanglements of debt and obligation.

Anthropologists have often returned to the classic argument - made by both Marx (2000 [1946]) and Simmel (1978 [1900]) - that, by enabling people to imagine material transactions as devoid of any moral specificity, liberalized markets are corrosive of social relations. For many people in newly capitalized societies, this desocialization of economic relations is experienced as a source of extreme moral anxiety (e.g. Taussig 1980). However, in Tissana, the most vividly expressed anxieties seem to be focused in exactly the opposite direction. Viewed through the lens of a present in which the maritime economy is coming under ever-greater pressure, older residents reminisce about a time when the rapid growth of the commercial fishing industry had appeared to be ushering in a period of unprecedented economic simplicity. According to their wistful recollections, there had been a period on Tissana Wharf, however fleeting, when they seemed to have achieved something close to Simmel's vision of a monetary system in which 'man 
is free - free because he can sell everything, and free because he can buy everything' (1978 [1900]: 404).

As discussed in the introduction, a historical legacy of domestic slavery, and later patterns of exploitative patronage, have left people in Sierra Leone highly attuned to the ambivalent potential that gifts hold: to generate social relationships of solidarity, or ones that are defined by indebtedness and dominance. Today, a tension animating many aspects of everyday life in Tissana is how, through the strategic deployment of material gifts, people are able to nurture the relationships they depend upon for their survival, whilst simultaneously attempting to eschew other, potentially more exploitative or costly social entanglements. As the ethnography in this article has revealed, this tension is experienced by banda women, as they are obliged to demonstrate 'gratitude' to the boat owners who sell them fish at prices they can barely afford; it is felt by poor crewmen, as they decide whether it is preferable to be indebted to their bossman or to a powerful banda woman. But even relatively wealthy owners often feel oppressed by the weight of obligations imposed by the gift economy, as they face a wharf full of friends, relatives and dependents, all of whom feel entitled to a share of their too-small catch.

The accounts from the fishermen and banda women offer insight into a gendered economics that moves away from representing women as 
victims and instead reveals the complex impact of - and the anxieties that follow from - these increasingly enmeshed social and economic ties for both men and women. There need not be a direct conflict between emphasizing women's profound and deepening material vulnerability, as described in this article, and also the power of the tactics and strategies they employ to survive in these difficult economic conditions. Without implying that eroticism can overthrow deeper structures of inequality, Groes-Green has shown in urban Mozambique that, even in highly patriarchal societies, sexuality can sometimes become a 'space for female assertiveness' (2013: 103). In some contexts, my interlocutors did express concern about the vulnerability of young women to sexual exploitation - but in Tissana, as elsewhere in Sierra Leone, there is huge variation in the amount of social and economic power individual women are able to hold in their relationships with men. So, without taking the fishermen's salacious stories too literally, or allowing them to detract from the real hardship and vulnerability that shape most women's lives in the Yawri Bay, these tales are testimony to the complexity of cultural understandings of gendered power in this region (cf. Coulter 2009; McGovern 2015: 255). 


\section{REFERENCES}

Argenti, N. 2010. Things that don't come by the road: Folktales, fosterage, and memories of slavery in the Cameroon Grassfields. Comparative Studies in Society and History 52(2):224-254.

Bellman, B. 1984. The language of secrecy. New Brunswick: Rutgers University Press.

Béné, C. 2007. Women and fish-for-sex: transactional sex, HIV/AIDS and gender in African fisheries. World Development 36: 875-99.

Berlin, I., 1969 [1958], Two concepts of liberty. In Four essays on liberty. London: Oxford University Press.

Bledsoe, C. 1980. The manipulation of Kpelle social fatherhood. Ethnology 19(1): 29-45. 
. 1984. The political use of Sande ideology and symbolism. American Ethnologist 11(3): 455-72.

Bohannan, P. 1959. The impact of money on an African subsistence economy. Journal of Economic History 19: 491503.

Bolten, C. 2008. 'This place is so backward': durable morality and creative development in northern Sierra Leone'. PhD Thesis, University of Michigan.

Burkhalter, B, and R.F. Murphy. 1989. Tappers and sappers: rubber, gold and money among the Mundurucu. American Ethnologist 16: 100-16.

Cornwall, A. 2002. Spending power: Love, money, and the reconfiguration of gender relations in Ado-Odo, southwestern Nigeria. American Ethnologist, 29(4): 963-80.

Coulter, C. 2009. Bush wives and girl soldiers: women's lives through war and peace in Sierra Leone. Ithaca, NY: Cornell University Press. 
Diggins, J. 2015. Economic runaways: patronage, poverty and the pursuit of 'freedom' on Sierra Leone's maritime frontier. Africa 85: 312-332.

. 2017. Potato rope families: sharing food and precarious kinship in a West African fishing town. Social Anthropology/Anthropologie Sociale 25(4): 493-508

EJF. 2012. Pirate Fishing Exposed: The Fight Against Illegal Fishing in West Africa and the E.U. London: Environmental Justice Foundation.

Ferme, M. 2001. The underneath of things: violence, history and the everyday in Sierra Leone. Berkeley: University of California Press.

Gale, L. A. 2006. Sustaining relationships across borders: gendered livelihoods and mobility among Sierra Leonean refugees. Refugee Survey Quarterly 25.2: 69-80. 
Gregory, C.A. ([1982]:2015) Gifts and Commodities, 2nd edition. Chicago: HAU Books.

Groes-Green, C. 2013. "To put men in a bottle": Eroticism, kinship, female power, and transactional sex in Maputo, Mozambique. American Ethnologist 40 (1):102-117.

Hau'ofa, E. 1993. Our sea of islands. In A new Oceania: rediscovering our sea of islands (eds) V. Naidu, E. Waddell, \& E. Hau'ofa, 2-16. Suva: School of Social and Economic Development.

Hunter, M. 2010. Love in the time of AIDS: inequality, gender, and rights in South Africa. Bloomington: Indiana University Press.

Kopytoff, I., \& S. Meirs. 1977. African 'slavery' as an institution of marginality. In Slavery in Africa: historical and anthropological approaches (eds) I. Kopytoff \& S. Meirs, 3-85. Wisconsin: University of Wisconsin Press. 
Leach, M. 1994. Rainforest relations: gender and resource use among the Mende of Gola, Sierra Leone. Edinburgh: Edinburgh University Press.

Marx, K. 2000 [1946]. The German ideology. In Karl Marx: selected writings (ed.) D. McLellan, 175-208. Oxford: Oxford University Press.

Mauss, M. 2002[1925]. The Gift: the form and reason for exchange in archaic societies. London and New York: Routledge.

Menzel, A. 2016. 'Betterment versus complicity: struggling with patron-client logics in Sierra Leone', in Højbejerg, C.K., J. Knörr and W.P. Murphy, eds. Politics and Policies in Upper Guinea Coast Societies: Change and Continuity. London: Palsgrave MacMillan

McGovern, M. 2015. Liberty and moral ambivalence: postsocialist transitions, refugee hosting, and bodily comportment in the Republic of Guinea. American Ethnologist 42(2): 246-261. 
Menzel, A. 2016. Betterment versus complicity: struggling with patron-client logics in Sierra Leone. In Politics and Policies in Upper Guinea Coast Societies: Change and Continuity (eds) Højbejerg, C.K., J. Knörr and W.P. Murphy. London: Palsgrave MacMillan

Peters, K. 2010. Generating rebels and soldiers: On the socioeconomic crisis of rural youth in Sierra Leone before the war. In, The Powerful Presence of the Past: Integration and Conflict along the Upper Guinea Coast (eds) J. Knörr and W.T. Filho, 323-55. Leiden: Brill.

Piot, C. (1999) Remotely Global: village modernity in West Africa. Chicago: University of Chicago Press.

Richards, P. 2005. To fight or to farm? Agrarian dimensions of the Mano River conflicts (Liberia and Sierra Leone). African Affairs 104(417): 571-90.

Rose, N., 1999. Powers of freedom: Reframing political thought. Cambridge: Cambridge University Press. 
Shaw, R. 2002. Memories of the slave trade: ritual and the historical imagination in Sierra Leone. Chicago: University of Chicago Press.

Simmel, G. 1978 [1900]. The Philosophy of Money. London: Routledge and Kegan Paul.

Taussig, M. 1980. The Devil and Commodity Fetishism in South America. Chapel Hill: University of North Carolina Press.

Thomas, L.M., and J. Cole. 2009. Thinking through love in Africa. In Love in Africa (eds) L.M. Thomas and J. Cole, 1-30. Chicago: University of Chicago Press.

Wardlow, H. 2004. Anger, economy, and female agency: problematising 'prostitution' and 'sex work' among the Huli of Papua New Guinea. Signs 26(4):1017-1040.

Westaway, E., J. Seeley, \& E. Alison. 2007. Feckless and reckless or forbearing and resourceful? Looking behind the 
stereotypes of HIV and Aids in Fishing Communities. African Affairs 106: 663-79.

Winterbottom, T. 1803. An Account of the Native Africans in the Neighbourhood of Sierra Leone. London: Whittingham.

Zelizer, V.A. 2005. The Purchase of Intimacy. Princeton: Princeton University Press. 


\section{ACKNOWLEDGEMENTS}

This article is based on research funded by a grant from the Economic and Social Research Council. I am very grateful to Elizabeth Mills, Elizabeth Hallam, James Fairhead, Dinah Rajak, Nicholas Argenti, Andrea Cornwall and David Pratten for their comments on earlier drafts of this paper.

\section{NOTE ON CONTRIBUTOR}

Jennifer Diggins is Senior Lecturer in Anthropology at Oxford Brookes University. Her research, in Sierra Leone, traces how understandings of intimacy, interdependence, and exploitation have been shaped through a history of indentured labour, violence, and gendered migration; and how these relationships are being renegotiated once more in a context of deepening economic uncertainty.

\section{CONTACT DETAILS}

jdiggins@brookes.ac.uk 
Dr Jennifer Diggins

Senior Lecturer in Social/Cultural Anthropology

Department of Social Sciences

Oxford Brookes University,

Headington Campus, Oxford

OX3 OBP

i In some cases, women work with money lent to them by traders. 